\title{
Kajian Naskah dan Kajian Living Qur'ān dan Living Hadith
}

\author{
Muhamad Ali ${ }^{1}$
}

\begin{abstract}
This article surveys contemporary works on Qur'ān and hadith, particularly in the West (and some examples of some works in the Middle East and in Indonesia). It asserts that textual study of the Qur'an and hadith is still important and needs to be improved, but it argues for more studies on living Qur'ān and living Hadith. Some weaknesses of textual studies can be complemented by the strengths of practical and contextual studies, and vice versa, the weaknesses of contextual and practical studies can be complemented by textual studies.
\end{abstract}

\begin{abstract}
Abstrak
Tulisan ini merupakan survey kajian-kajian kontemporer tentang al-Qur'ān dan hadith, khususnya di Barat (dengan beberapa contoh kajian di Timur Tengah dan Indonesia). Tulisan ini berpendapat bahwa kajian Naskah al-Qur'ān dan hadith tetap penting dan harus dikembangkan, namun menawarkan kajian Living Qur'ān dan Living Hadith. Kelemahan-kelemahan pada kajian naskah tekstual dapat ditutupi dengan kelebihan-kelebihan kajian kontekstual praktikal, dan sebaliknya, kekurangankekurangan pada kajian kontekstual dapat ditutupi dengan kajian tekstual.
\end{abstract}

Keywords: Living Qur'ān, Living Hadith, kajian teks dan naskah, lived religion, scripture, informative-performative-transformative

\section{Pengantar}

Dalam buku-buku tentang metodologi studi Islam, baik menurut satu disiplin ilmu tertentu maupun yang interdisipliner, penelitian dimensi praktikal dan kontekstual kitab suci al-Qur'ān dan hadith Nabi belum mendapatkan tempat sebagaimana kajian naskah dan tekstual. Salah satu buku itu, misalnya, menguraikan pengertian al-Qur'ān, hikmah diturunkannya secara bertahap, garis

${ }^{1}$ Associate Professor, Religious Studies Department, University of California, Riverside; Dosen Fakultas Ushuluddin, Tafsir Hạdith, UIN Syarif Hidayatullah Jakarta. Alamat email: muhamadalimiqdar@gmail.com 
besar kandungan al-Qur'ān, metode penafsiran al-Qur'ān, beberapa kesalahan dalam menafsirkan Al-Qur'ān, ruang lingkup studi Hadith dan fungsi hadith, dan memisahkannya dari pendekatan-pendekatan lain seperti antropologis, sosiologis, psikologis, dan metode-metode seperti fenomenologi dan sosiohistoris. ${ }^{2}$ Hal ini karena al-Qur'ān dan hadith adalah teks tertulis dan karena tradisi keilmuan ilmu al-Qur'ān dan ilmu hadith sudah sangat lama, otoritatif, dan self-sufficient. Tulisan berikut ini mengantarkan diskusi mengenai kajian naskah kontemporer sebelum menawarkan penelitian Living Qur'ān dan Living Hadith, melalui review singkat karya-karya kontemporer yang bisa masuk kategori penelitian praktikal, khususnya di Barat, baik oleh sarjana Muslim maupun non-Muslim, sekaligus menyentuh beberapa karyakarya yang mengambil obyek kajian literatur dan masyarakat Muslim di Indonesia.

\section{Kajian Naskah: Tematik dan Metodologis}

Dalam kitabnya tentang al-Qur'ān dan manusia, mufassir dan sastrawan perempuan asal Mesir, ' $\bar{A}$ ’ishah Abd al-Rahman Bint al-Shāți' mengakui bahwa perhatian pada hak-hak manusia di zaman modern membuat para mufasir harus membahasnya juga dari perspektif al-Qur'ān. ${ }^{3}$ Bint al-Shāti' mengkaji ayat-ayat al-Qur'ān yang berkaitan dengan insān dan kata-kata lain terkait seperti bashar, asal usul manusia dan tugas-tugasnya di muka bumi. Ia pun menelaah gagasan kebebasan manusia (hurriyyat al-insān), kebebasan keyakinan (hurriyyat alaqìiah), dan kebebasan kehendak (hurriyyat al-irädah) dari perspektif alQur'ān. ${ }^{4}$ Kajian tafsir tematik kontemporer seperti ini, bahkan makin populer di Indonesia, seperti terlihat dari penerbitan buku-buku: ayat-ayat ahkam, ayatayat wanita, ayat-ayat ekonomi, ayat-ayat pendidikan, ayat-ayat sains \& sosial, ayat-ayat sosial budaya, ayat-ayat sosial politik, ayat-ayat haji, ayat-ayat kebahagiaan, ayat-ayat kematian, dan masih banyak lagi. ${ }^{5}$ Tafsir-tafsir naskah

${ }^{2}$ Dede Ahmad Ghazali dan Heri Gunawan, Studi Islam: Suatu Pengantar dengan Pendekatan Interdisipliner (Bandung: Remaja Rosdakarya, 2015), 83-132.

3 'Ā'ishah Abd al-Rahman Bintu Al-Shātị', Al-Qur'ān wa Qaḍāāa al-Insān (Kairo: Dar al-Ma'arif, tanpa tahun), 6.

${ }^{4}$ Bintu Al-Shātị', Al-Qur'ān wa Qaḍ̂āà al-Insān, 7-250.

${ }^{5}$ Mengenai tafsir maudù,'i, lihat misalnya, Muhammad Al-Ghazāì, Naḥwa al-

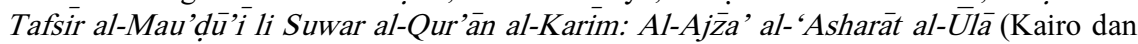
Beirut: Dār al-Shurūq, 1992). Di Indonesia, buku Ilmu-Ilmu Al-Qur'an yang diterbitkan Biro Bina Mental Spiritual DKI Jakarta membahas metode-metode penafsiran al-Qur'ān,

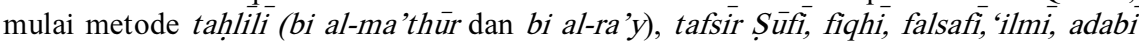

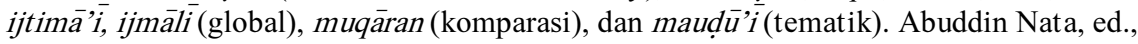
Ilmu-ilmu Al-Qur'an, Bagian 1 (Jakarta: Biro Bina Mental Spiritual DKI Jakarta, 1993/1993), 145-79. Nashruddin Baidan membahas teori evolusi, perkawinan campuran, 
tematik ini menggunakan sumber naskah teks al-Quran dan produk-produk penafsiran yang memuat kandungan al-Qur'ān (maḍūn al-Qur'ān). Pada saat yang sama, kajian metode para mufassir (manāhij al-mufassirīin) dan kaedahkaedah penafsiran ( $q a w \bar{a}$ 'id al-tafsiri, usūl al-tafsir) tetap dilakukan, meski tidak sebanyak kajian tematik di atas. ${ }^{6}$ Kajian naskah atas metodologi al-Qur'ān di Barat dapat ditemukan dalam buku Structure and Qur'ānic Interpretation: A Study of Symmetry and Coherence in Islam's Holy Text, karya Raymond Farrin, ${ }^{7}$ yang membahas simetri dan keterpaduan teks al-Qur'ān.

\section{Kajian Naskah Tematik Metodologis: Perspektif Jender dan Pluralisme}

Mulai bermunculan kajian naskah tematik sekaligus metodologis, seperti pendekatan jender dan pluralisme. Di Amerika, Amina Wadud, dalam Qur'ān and Women: Rereading the Sacred Text from a Woman's Perspective menawarkan pembacaan feminis Muslim tentang kesetaraan dan keadilan jender, dengan menafsirkan ulang ayat-ayat tentang penciptaan manusia, termasuk konsep nafs dan zawj, konsep taqwa, kesamaan balasan dan hukuman, dan kontroversi-kontroversi seputar darajah, faḍala, nush $\bar{u} z$, poligami, warisan, dan pengawasan anak. ${ }^{8}$ Kajian Aysha A. Hidayatullah, Feminist Edges of the Qur'ān ${ }^{9}$ menguraikan kemunculan tafsir feminis di zaman kontemporer, tiga metode penafsiran mereka (metode kontekstualisasi historis, metode intratekstual, dan metode tawhidik) dan memberikan beberapa kritik terhadap tafsir feminis ini.

Jerusha Tanner Lamptey, dalam bukunya Never Wholly Other: A Muslim Theology of Religious Pluralism, membahas perdekatan feminis Muslim terhadap al-Qur'ān dan melihat konsep-konsep ïmān, isläm, kufr, shirk, dalam kerangka konsep taqwā: menyimpulkan bahwa wacana al-Quran tentang perbedaan agama itu bersifat dinamis, ambigus (tidak jelas), dan kompleks.

etika ekonomi Islam, penanggulangan AIDS, dan sebagainay, penafsiran 'sebagai solusi Qur'āni at as masalah kontemporer'. Nashruddin Baidan, Tafsir Maudhu'i: Solusi Qur'ani atas Masalah Sosial Kontemporer(Yogyakarta: Pustaka Pelajar, 2001).

${ }^{6}$ Mayoritias dosen dan mahasiswa di Indonesia melakukan kajian naskah. Sekedar contoh saja, saya menguji skripsi "Konsep Naskh menurut Abdullahi Ahmed An-Na'im dan Jasser Auda" oleh Ahmad Karomain; "Semantik Al-Qur'ān menurut Aisyah Abd Al-Rahman Bintu Al-Syathi' dan Toshihiko Izutsu” oleh Ahmad Royani, dan lain-lain.

${ }^{7}$ Raymond Farrin, Structure and Qur'ānic Interpretation: A Study of Symmetry and Coherence in Islam's Holy Text (While Cloud Press, 2014).

${ }^{8}$ Lihat Amina Wadud, Qur'an and Women: Rereading the Sacred Text from a Woman's Perspective (London: Oxford University Press, 1999).

${ }^{9}$ Aysha A. Hidayatullah, Feminist Edges of the Qur'ān (London dan New York: Oxford University Press, 2014) 
Mun'im A. Sirry, dalam Scriptural Polemics: the Qur'ān and Other Religions ${ }^{10}$ membahas scripture dalam kerangka hubungan teks dan pembacanya: bahwa makna tidak satu dan dinamis. Sirry sepakat dengan ulama Muslim yang tidak mempersoalkan kemutawatiran otentisitas penulisan al-Quran (Mekah awal, tengah, akhir, Madinah awal, tengah dan akhir). Ia berargumen bahwa pernyataan-pernyataan al-Qur'ān tentang Yahudi dan Kristen lebih bersifat polemik ketimbang menggambarkan doktrin Yahudi dan Kristen apa adanya. Ia juga mengajak mengatasi polemik kitab suci dalam konteks mengobati saling praduga dan kebencian umat beragama saat ini.

\section{Living Qur'ān dan Hadith sebagai Bagian Lived Texts, Lived Islam}

Dalam kajian agama, kajian Living Qur'ān dan Hadith adalah bagian dari kajian 'lived Religion, 'practical religion', 'popular religion', 'Iived Islam', yang bertujuan menggali bagaimana manusia dan masyarakat memahami dan menjalankan agama mereka, untuk tidak mengutamakan kaum elit agama (pemikir, otoritas agama, pengkhotbah, dan sebagainya). Metode-metode saintifik sosial memasuki wilayah kajian agama dan para sarjana beralih dari kajian naskah kepada kajian masyarakat beriman pada masa kini (present-day living communities of faith). ${ }^{11}$ Dalam kajian kitab suci perbandingan (comparative scripture), Living Qur'ān dan Hadith menjadi bagian dari kajian the uses of scripture, yang belum begitu berkembang juga. Kajian-kajian antropologis umumnya melakukan pendekatan aspek praktis pemahaman dan pengamalan agama, seperti simbol, mitos, ritual, samanisme, magis, tapi belum banyak yang membahas aspek pemahaman, penggunaan, dan pengamalan kitab suci dalam kehidupan sehari-hari. ${ }^{12}$ Jika scripture diartikan sebagai tulisan yang diterima dan digunakan dalam komunitas agama sebagai suci dan otoritatif maka al-Qur'ān dan Hadith masuk definisi ini, sebagaimana juga kitab-kitab Zoroaster, Yahudi, Kristen, dan Sikh, yang disebut "agama-agama kitab" (religions of the book). Ada tiga macam penggunakan kitab suci.

Pertama, penggunaan kognitif, pemahaman dan pemikiran tentang kata dan maknanya. Penggunaan kognitif ini mencakup beberapa macam. Salah

${ }^{10}$ Mun'im A. Sirry, Scriptural Polemics: the Qur'ān and Other Religions (London dan New York: Oxford University Press, 2015).

${ }^{11}$ Lihat misalnya, Jane F. Maynard et al, eds, Pastoral Bearings: Lived Religion and Pastoral Theology (New York: Lexington Books, 2010); Robert E. van Voorst, Anthology of World Scriptures (Belmont, CA: Thomson Wasworth, 2008), 3.

${ }^{12}$ W.A. Lessa dan E.Z. Vogt, edisi ke-4, Reader in Comparative Religion: An Anthropological Approach (New York: Harper dan Row, 1997), dalam van Voorst, Anthology of World Scriptures, footnote 5, halaman 3. 
satunya, kitab suci menjadi sumber membangun dan mempertahankan doktrindoktrin atau ajaran-ajaran, kebenaran-kebenaran tentang semesta dan cara yang benar untuk hidup didalamnya. Ketika kitab suci digunakan untuk membangun doktrin maka 'para penafsir resminya' - seperti pendeta, ulama, dan sejenisnya, paling sering melakukannya. Merujuk kepada kitab suci sering kali menjadi kata akhir argumen-argumen agama. Termasuk dalam penggunaan kognitif adalah penggunaan teks dalam ritual publik. Kitab suci dibaca, dilagukan, dilingkari, dicium, dihias, diletakkan pada posisi tinggi dan dimuliakan, dalam ritual pengorbanan, dan sebagainya. Dalam tradisi Kristen, ada istilah biblioatry, penyembahan pada kitab, ketika orang yang mengimani memberikan penyembahan yang sangat dalam dan menganggap kitab sebagai mutlak. Selanjutnya, penggunaan dalam meditasi dan kebaktian yang bersifat pribadi dan kelompok.

Kedua, penggunaan non-kognitif kitab suci terjadi dalam banyak situasi. Kitab suci dipajang di rumah dan bangunan-bangunan publik, dan ditulis dalam kaligrafi. Selain itu, kitab suci memiliki kekuatan (power) memberikan berkah (barakah, blessing), menyembuhkan penyakit, menolak bala dan kejahatan, digunakan sebagai mantra dan jimat, ketika diam dan ketika bepergian. Bagi umat Dao, misalnya, kitab suci Dao diletakkan pendetanya di tangan ibu yang sedang melahirkan agar diberi kemudahan. Dalam tradisi Islam, kitab suci alQur'ān atau potongan ayat digunakan atau dibacakan kepada orang yang sakit. Penggunaan lainnya, disebut Bibliomancy, ketika kitab suci digunakan untuk memperkirakan masa depan dan membimbing orang bersangkutan bagaimana menghadapi masa depan itu. Orang Sikh misalnya membuka halaman berapa saja dari Kitab Guru Grant Sahib pada satu hari dan menjadikannya sebagai petunjuk kehidupannya hari itu. ${ }^{13}$

Penggunaan kitab suci juga bisa dikaji dari segi informative dan segi performative. Dari segi informatif, kitab suci dijadikan sumber pengetahuan, doktrin, sejarah masa lalu, isyarat ilmu pengetahuan, dan sebagainya. Dari segi performatif, kitab suci dialami, dijadikan sebagai barang suci, misalnya dalam ritual kurban, dijadikan sumber hukum negara atau masyarakat, dijadikan alat untuk memberkahi, dilagukan dan dilombakan, dan sebagainya. Secara umum, kitab-kitab suci memiliki kekuatan merubah (transformative power) dalam kehidupan pribadi maupun masyarakat yang mengimaninya. ${ }^{14}$

Ada kelebihan dan kekurangan kajian yang memfokuskan kitab suci sebagai cara memahami agama-agama. Kelebihan-kelebihan kajian skriptural

\footnotetext{
${ }^{13}$ van Voorst, Anthology of World Scriptures, 8-10.

${ }^{14}$ van Voorst, Anthology of World Scriptures, 10.
} 
cukup banyak. Kitab suci ada di hampir semua agama. Kitab suci cenderung komprehensif bagi keimanan umat beragama. Kitab suci dianggap otoritatif bagi agama-agama mereka. Kitab suci menjadi sumber memahami agamaagama. Kitab suci juga terbuka untuk dikaji dari berbagai pendekatan, termasuk pendekatan tekstual, literary, sastrawi. ${ }^{15}$ Di sisi lain, kajian skriptural memiliki kekurangan-kekurangan. Kekurangan yang pertama, penerimaan dan penggunaan kitab suci tidak seragam dalam agama-agama. Kaum beriman menganggap kitab suci mereka secara berbeda, dan kitab-kitab suci yang berbeda itu berfungsi secara berbeda pula. Kekurangan kedua, adalah terjemahan kitab suci tidak seluruhnya menangkap makna asli. Kekurangan ketiga, pendekatan skriptural sering kali bersifat elit dan patriarkal. Kekurangan keempat, fokus kepada teks kitab suci semata kurang konteks hidup teks itu. Untuk kajian al-Qur'ān dan hadith, yang diyakini memiliki kekuatan otoritatif utama dan kedua, kelemahan-kelemahan kajian tekstual ditutupi dengan kajiankajian living texts, teks atau scripture sebagaimana dipahami dan dijalankan penganutnya.

\section{Kajian Living Qur'ān: Apa dan Mengapa?}

Secara umum, kajian Living Qur'ān (dan Living Hadith) artinya mengkaji al-Qur'ān dan/atau hadith sebagai teks-teks yang hidup, bukan teksteks yang mati. Pendekatan Living Qur'ān menekankan aspek fungsi al-Qur'ān sebagai petunjuk dan rahmat bagi manusia dan orang-orang yang beriman, tapi ini juga bisa memasukkan peranan al-Qur'ān dan hadith dalam berbagai kepentingan dan konteks kehidupan, baik yang beriman maupun yang tidak beriman. Pendekatan ini juga mengkaji produk penafsiran dan relevansinya bagi persoalan masyarakat kini dan di sini. Al-Qur'ān merupakan firman lisan (spoken word), bersamaan atau belakangan lalu menjadi scripture (kitab) dan kemudian menjadi literature. Kajian al-Qur'ān memberikan sumbangsih bagi pemahaman tentang scripture dan literature dalam studi agama-agama. Bagi William Graham yang membahas makna kitāb, Qur'ān, kalām, dhikr, qirā’ah, al-Qur'ān adalah firman tertulis yang dilisankan (a written word that is spoken). Karenanya, kajian teks agama harus melampaui firman lisan dan firman tertulis. $^{16}$

${ }^{15}$ van Voorst, Anthology of World Scriptures, 10-11.

${ }^{16}$ William Graham, “The Qur'àn as Spoken Word: An Islamic Contribution to the Understanding of Scripture," Richard Martin, ed., Approaches to Islam in Religious Studies (Oxford: Oneworld, 2001), 23-40. 
Dalam kaitan ini, al-Qur'ān yang dibaca dalam kegiatan sehari-hari Muslim menjadi bagian kajian Living Qur'ān. Bagi Muslim yang bertujuan menjadikan al-Qur'ān tetap relevan di zaman sekarang, perspektif Living Qur'ān menjadikan al-Qur'ān lebih membumi. ${ }^{17}$ Karya Nasaruddin Umar, Deradikalisasi Pemahaman Al-Qur'an \& Hadis, misalnya, adalah contoh upaya mengkombinasikan Living Qur'ān dan Hadith dengan menggunakan kajian naskah yang dikontekstualisakan demi kepentingan umat Islam dan Indonesia. ${ }^{18}$

Kajian Living Qur'ān yang berorientasi akademis ilmiah, tidak terlalu memperhatikan perdebatan otentisitas Al-Qur'ān, perdebatan perbedaan metode, kaedah, dan produk tafsir zaman klasik, pertengahan, dan modern, dan perdebatan pemaksaan atau bukan pemaksaan. Dalam kajian Living Qur'ān, tidak ada perhatian pada penyimpangan-penyimpangan dalam penafsiran al-

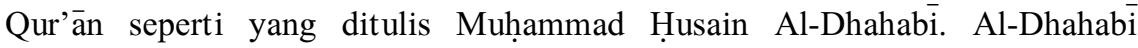
menguraikan penyimpangan-penyimpangan tafsir sejarawan, ahli tata bahasa Arab, Mu'tazilah, Syiah Imamiyyah, khawarij, Sufi, ilmuwan, dan pembaharu. ${ }^{19}$ Kajian akademis murni tidak memperhatikan apakah ada kedangkalan penafsiran. Living Qur'ān dalam corak ini menunjukkan bahwa setiap penafsiran atau pemahaman terhadap al-Qur'ān benar menurut manusia pemahamnya. Kajian ini lebih memfokuskan pada peran praktis al-Qur'ān dalam pemahaman, sikap, perilaku, aktifitas manusia sebagai individu ataupun masyarakat, terlepas apakah pemahaman, sikap, perilaku, dan aktifitas itu berdasarkan pengetahuan akan kaedah tafsir ataupun tidak sama sekali. Pemahaman al-Qur'ān bisa saja sepotong-potong, tidak berdasarkan munasabah ayat lain, tidak berdasarkan pengetahuan sabab nuzūl, tidak berdasarkan siyāq (situasi pembicaraan) atau tidak berdasarkan pemahaman bahasa Arab. Pemahaman al-Qur'ān bisa saja dianggap keras, tidak toleran, bahkan militan dan radikal. Tugas pengkaji Living Qur'ān yang semacam ini adalah mengkaji konteks ruang dan waktu subyek manusia bagaimana dan mengapa mereka memahami dan menerapkan al-Qur'ān itu apa adanya, as they do, the way they do.

Perhatian Living Qur'ān ini lebih pada tataran pemahaman, bukan pada tafsir, jika kita mengikuti pendapat Bintu Shăti’ yang membedakan al-fahm dan

${ }^{17}$ Lihat misalnya M. Quraish Shihab, Membumikan Al-Qur'ān, jilid 1 dan jilid 2 (Bandung: Mizan, 2008).

${ }^{18}$ Nasaruddin Umar, Deradikalisasi Pemahaman Al-Qur'an \& Hadis (Jakarta: Gramedia, 2014).

19 Muhammad Husein Adz-Zhahabi, Penyimpangan-penyimpangan dalam Penafsiran Al-Qur'an, terj. Hamim Ilyas dan Machnun Husein, Al-Ittijāhät alMunharifah fi Tafsir al-Qur'ān al-Karim (Jakarta: Rajawali, 1991). 
al-tafsir. Ia berpendapat, "Antara hak setiap manusia untuk memahami AlQuran untuk dirinya, dan dikatakan bahwa menafsirkannya pun dibolehkan untuk siapa yang mau." Menurutnya, al-Qur'ān adalah kitab umat Islam semuanya, setiap Muslim mendengarnya, menerapkan maknanya sesuai dengan kemampuan mereka. Namun demikian, Bintu Shāți’ melanjutkan, al-Quran juga adalah kitab seluruh manusia, yang beragama dan tidak beragama. Ia berpendapat, para Orientalis, dari Kristen, Yahudi, agnostik dan ateis, mengkaji dan memahami al-Qur'ān dan mengemukakannya kepada kaum mereka apa yang mereka pahami dari kitab ini tentang aqidah Islam, kesatuan umat, tentang agama, rasionalitas dan karakteristik umum lainnya. Menurutnya, umat Islam lebih berhak lagi memahami al-Qur'ān sesuai dengan kemampuan mereka. Tidaklah terlalu penting mereka harus belajar ilmu-ilmu Islam dan seluk beluk bahasa al-Qur'ān, sambil mengutip ayat "Dan tidaklah pemberian Tuhan itu dihalangi” (Al-Isra:20). Namun, Bintu Shāți’ menjelaskan, pemahaman tidak sama dengan penafsiran di mana seorang mufasir mengemukakan penafsirannya terhadap nas al-Qur'ān kepada orang lain, haruslah tahu seluk beluk bahasa, pemahaman, konteks, dan pengambilan hukumnya." ${ }^{20}$

Bagi pengkaji berorientasi akademis, kajian Living Qur'ān artinya memahami dan menjelaskan mengapa dan bagaimana al-Qur'ān dipahami sebagaimana adanya, bukan sebagaimana yang seharusnya menurut kaidahkaidah tafsir itu. Ia tidak mengkaji sejauh mana pemahaman dan penerapan alQur'ān itu memenuhi sebagian atau tidak kaedah-kaedah penafsiran yang dianggap otoritatif.

\section{Living Qur'ān: Kognitif dan Non-Kognitif}

Kajian Living Qur'ān tidak terbatas pada pemahaman kognitif terhadap ayat-ayat al-Qur'ān. Kajian Living Qur'ān ini memberikan perhatian pada motivasi dan aktifitas Muslim dalam menghapal, membaca, melantunkan, melombakan bacaan al-Qur'ān, menulis kaligrafi, dan menggunakan al-Qur'ān dalam peraturan, dokumen resmi. Living Qur'ān juga memasukkan berbagai cara mendekati al-Qur'ān dengan mengutamakan dimensi rasa (emotion). Karya Anna Gade, Perfection Makes Practice: Learning, Emotion, and the Recited Qur'an $^{21}$ mencoba mengkaji mood (rasa) dan motivasi muslim Indonesia ketika mempelajari cara membaca dan menghapal al-Qur'ān. Anna Gade, yang menguasai bahasa Arab dan bahasa Indonesia, mengamati pelajaran membaca

${ }^{20}$ Bintu Shāṭi', Al-Qur'ān wa Qaḍayāa al-Insān, 313-17.

${ }^{21}$ Anna Gade, Perfection Makes Practice: Learning, Emotion, and the Recited Qur'ān in Indonesia (Honolulu: University of Hawai'i Press, 2004). 
dan melagukan al-Qur'ān di Makassar selama sepuluh bulan pada tahun 1996 dan ia melakukan wawancara pakar tilawah Al-Quran. Gade memposisikan pembacaan al-Qur'ān di Indonesia dalam konteks yang lebih panjang tradisi keagamaan Islam, bukan sekedar dalam konteks politik Orde Baru. Buku ini dimulai dengan pendahuluan tentang pembacaan (recitation), diikuti bab-bab tentang keterampilan menghapal (memorization), membaca (literacy), penampilan dalam panggung (performance), dan perlombaan (competition). Argumen utamanya adalah, emosi yang dikonstruk secara sosial memiliki peran yang sama dengan sistem kognitif dan sosial dalam menciptakan dan mendukung keberlangsungan Islam. ${ }^{22}$

Dalam kaitan ini, "musikalitas keagamaan" menjadi aspek menarik ketika rasa, bakat, dan internalisasi diteliti, misalnya dalam konteks Indonesia. Internalisasi, seperti didefinisikan Gade, adalah proses di mana pesan-pesan dan makna-makna sosial dirasakan, dipikirkan dan dialami. Mengikuti antropolog Clifford Geertz mengenai "modes and motivations", Gade menjelaskan peranan emosi dalam peristiwa pembacaan al-Qur'ān di Indonesia. ${ }^{23}$ Anne Rasmussen, seorang sarjana Etnomusikologi, guru, dan pemain musik Arab, dalam bukunya Women, the Recited Qur'an, and Islamic Music in Indonesia, ${ }^{24}$ mengkaji secara etnografis, pembacaan al-Qur'ān qari'ah Maria Ulfah di Indonesia kontemporer dari konteks global, nasional, dan lokal. Ia melihat bagaimana penguasaan bahasa Arab, tradisi lisan, norma "ramai', dan gender berkaitan satu sama lain dalam tradisi seni baca al-Qur'ān di Indonesia kontemporer. ${ }^{25}$

Dimensi jender dalam Living Qur'ān menarik banyak sarjana, termasuk Pieternella van Doorn-Harder ${ }^{26}$ yang mengkaji bagaimana perempuanperempuan Muslim Indonesia, dari Aisyiah dan Muslimat NU, membaca dan memahami al-Qur'ān di Indonesia, bagaimana mereka berpikir dan bergerak dalam soal-soal keluarga, pernikahan, kontrol kelahiran, dan poligini atau

${ }^{22}$ Thomas Gibson, "Review of Perfection Makes Practice," Indonesia 79 (April 2005), 183-185; Muhamad Ali, "Review of Perfection Makes Practice," The American Journal of Islamic Social Sciences 23, 3 (2006): 89-91;

${ }^{23}$ Anna Gade, "Taste, Talent, and the Problem of Internalization: A Qur'anic Study in Religious Musicality from Southeast Asia," History of Religions 41, 4 (May 2002): 328-68.

${ }^{24}$ Anne K. Rasmussen, Women, the Recited Qur'ān, and Islamic Music in Indonesia (Berkeley: University of California Press, 2010).

${ }^{25}$ Kristina Nelson, "Review of Anne K. Rasmussen, Women, the Recited Qur'ān, and Islamic Music in Indonesia," Review of Middle East Studies 46, 1 (Summer 2012): 134-6; Anne Rasmussen, "The Qur'ān in Indonesian Daily Life: the Public Project of Musical Oratory," Ethnomusicology 45, 1 (Winter 2001): 30-57.

${ }^{26}$ Pieternella van Doorn-Harder, Women Shaping Islam: Reading the Qur'ān in Indonesia (Urbana: University of Illinois Press, 2006). 
poligami. Pieternella berpendapat, Aisyiyah menekankan ayat-ayat al-Qur'ān tentang kesejajaran jender dan tidak mengambil rujukan dari tradisi fiqih, dan karena itu tidak berhasil mereformasi wacana fiqih yang berperan di masyarakat Muslim Indonesia. Muslimat NU di sisi lain, menurutunya, memperlihatkan kedalaman tradisi fiqh dalam soal ini yang bisa dianggap liberal. ${ }^{27}$

Lebih jauh lagi, kajian Living Qur'ān ini membahas dimensi praktikal, bagaimana kaum Muslim menggunakan al-Qur'ān untuk keperluan magis, amulet, penyembuhan penyakit jasmani dan ruhani; bagaimana mereka menggunakan al-Qur'ān untuk kepentingan bisnis dan ekonomi; bagaimana mereka menggunakan al-Qur'ān untuk ceramah-ceramah populer di TV, di tulisan koran, di media sosial, dan sebagainya; bagaimana mereka menggunakan al-Qur'ān dalam pendidikan. Contohnya adalah The Walking Qur'ān: Islamic Education, Embodied Knowledge, and History in West Africa karya Rudolph T. Ware III, ${ }^{28}$ yang membahas bagaimana al-Qur'ān berfungsi dalam kehidupan perbudakan dan revolusi melawannya, serta di dunia pendidikan di Afrika. Buku Farid Esack the Qur'ān, Liberation, and Pluralism: An Islamic Perspective of Interreligious Solidarity against Oppression juga masuk kategori ini.

Al-Qur'ān juga berpengaruh secara material seperti dalam kaligrafi dan arsitektur. Kajian yang cukup komprehensif adalah buku The Story of the Qur'an: Its History and Place in Muslim Life oleh sarjana dan aktifis perempuan Muslim asal Kanada Ingrid Mattson. ${ }^{29}$ Ingrid Mattson menjelaskan secara singkat sejarah al-Qur'ān, lalu doktrin-doktrin yang terkandung di dalamnya, dan membahas pengaruh al-Qur'ān dalam kehidupan personal, budaya pop, hukum, seni, arsitekture, sains, dan sastra.

Di Indonesia, kajian Living Qur'ān mulai dilakukan, namun belum cukup banyak. Howard Federspiel sudah memulai penelitiannya dalam karyanya Popular Literature of the Qur'an in Indonesia, ${ }^{30}$ yang membahas sekitar 60 karya tentang al-Qur'ān: yang elitis dan yang populer. Meskipun ia hanya mengumpulkan karya-karya Sunni, padahal ada karya-karya Syiah dan

${ }^{27}$ Nancy J. Smith-Hefner, "Review Pieternella van Doorn-Harder, Women Shaping Islam: Reading the Qur'ān in Indonesia," The Journal of Asian Studies 67, 2 (May 2008): 747-49.

${ }^{28}$ Rudolph T. Ware III, The Walking Qur'ān: Islamic Education, Embodied Knowledge, and History in West Africa (the University of North Carolina Press, 2014).

${ }^{29}$ Ingrid Mattson, The Story of the Qur'àn: Its History and Place in Muslim Life (Wiley-Blackwell, 2008).

${ }^{30}$ Howard M. Federspiel, Popular Indonesian Literature of the Qur'an (Ithaca: Cornell Univrsity Modern Indonesia Project, 1994). 
Ahmadiyah, dan karya yang mengingkari Sunnah, Federspiel berhasil melakukan review karya-karya ini secara apa adanya, tanpa penilaian kritis. ${ }^{31}$

Kajian-kajian naskah tentang pendekatan terhadap al-Qur'ān di Indonesia kontemporer sudah ada dan masih sangat penting. Esai-esai dalam buku Abdullah Saeed ${ }^{32}$ mencoba membahas Hamka, M. Quraish Shihab, dan sarjana Indonesia lainnya. Yusuf Rahman membahas H.B. Jassin, Lies MarcoesNatsir tentang aborsi, Ro'fah Mudzakir tentang poligami menurut Aisyiyah dan perspektif al-Qur'ān, dan tulisan Azyumardi Azra dan Nurcholish Madjid. Pendekatan al-Qur'ān di Indonesia ini menjadi bagian dari wacana Islam kontemporer yang lebih luas dan global, meskipun konteks lokal dan nasional berperan penting. ${ }^{33}$ Tentu saja manuskrip-manuskrip tafsir nusantara perlu digali dan dikaji dalam konteks historisnya.

Dalam artikel saya, "They are Not All Alike": Indonesian Muslim Intellectual's Perception of Judaism and Jews", saya mencoba menjelaskan faktor-faktor mengapa pemahaman dan penafsiran Muslim Indonesia umumnya bersifat ambigu, tapi makin beragam, dengan menggunakan beberapa penafsiran al-Qur'ān M. Quraish Shihab, pemahaman Alwi Shihab, Nurcholish Madjid, Abdul Moqsith Gazali, Zuhairi Misrawi, buku teks sekolah dan universitas, dan tokoh intelektual di Makassar, tentang Yahudi dan Israel. Pendapat yang ambigu itu karena tidak ada pembedaan Yahudi sebagai agama dan sebagai bangsa. Pandangan mereka dipengaruhi juga oleh bacaan terhadap al-Qur'ān khususnya Periode Madinah, dan sejarah Islam, Spanyol abad pertengahan, dan konflik Arab-Israel. Yahudi sebagai agama dan bangsa tidak dilihat dari sejarah mereka sendiri. ${ }^{34}$ Pendekatan ini salah satu contoh Living Qur'ān yang bersifat wawasan seperti ada dalam naskah, dengan memperhatikan konteks global dan lokal.

Masih minim kajian kontekstual terhadap literatur Qur'ān. Perlu dikaji bagaimana kelompok-kelompok Muslim, Ikhwanul Muslimin, Sayyid Qutb, Osama bin Laden, Al-Qaida, ISIS, atau Muslim Liberal, memahami dan

${ }^{31}$ Martin van Bruinessen, "Review of Popular Indonesian Literature of the Qur'ān,"Journal of Southeast Asian Studies 29, 1 (Maret 1998): 197-99.

${ }^{32}$ Abdullah Saeed (ed.), Approaches to the Qur'an in Contemporary Indonesia (London: Oxford University Press in association with the Institute of Ismaili Studies, 2005).

${ }^{33}$ Carool Kersten, "Review of Abdullah Saeed (ed.), Approaches to the Qur'an in Contemporary Indonesia," Bulletin of the School of Oriental and African Studies 69, 3 (2006): 499-501.

${ }^{34}$ Muhamad Ali, “'They Are Not All Alike': Indonesian Muslim Intellectuals' Perception of Judaism and Jews," Indonesia and the Malay World 38, 112 (November 2010): 329-47. 
menerapkan ayat-ayat tertentu, seperti ayat-ayat 'perang.' Kajian tentang bagaimana Muslim Indonesia memahami ayat-ayat tentang Islam dan agamaagama lain belum ada. Begitu pula kajian tentang bagaimana Muslim laki-laki dan perempuan memahami ayat-ayat tentang seksualitas dan gender. Perlu dikaji bagaimana mereka memilih dan memahami ayat-ayat tentang "keadilan" (sosial, gender, politik, ekonomi, dan sebagainya); bagaimana mereka memilih dan memahami ayat-ayat tentang kebebasan beragama, pluralisme, HAM, anti kekerasan, perdamaian, good governance, anti-korupsi, lingkungan hidup, dan sebagainya.

Dari segi lisan atau oral, kajian Living Qur'ān meneliti pembacaan, pembicaraan, ceramah, pendapat tentang makna ayat dalam konteks ruang dan waktu. Secara praktis, kita perlu meneliti bagaimana al-Qur'ān digunakan dalam selametan, kenduri, ratib, maulud, tahlilan, pengajian arisan, dan sebagainya. Begitu pula dalam bentuk praktik, penerapan ayat-ayat dalam konteks ruang dan waktu.

Tidak kalah menariknya adalah meneliti bagaimana al-Qur'ān terlembagakan. Di Indonesia ada pelembagaan simbol, nama, dan/atau nilai alQur'ān dalam organisasi, institusi pesantren al-Qur'ān, lembaga tahfiz alQur'ān, lembaga tafsir al-Qur'ān, lembaga tashih al-Qur'ān, lembaga pengkajian al-Qur'ān, pengorganisasian MTQ, STQ, dan sebagainya.

\section{Kajian Naskah dan Living Hadith}

Studi naskah ḥadith, riwāyat hadīth, dirāyah ḥadith, sharah hadith, dan takhrij hadith sangatlah penting dan relevan bagi pengembangan Ilmu Hadith dan Hadith di zaman sekarang dan ke depan. Karya M. Syuhudi Ismail Kaedah Kesahihahan Hadith: Telaah Kritis dan Tinjauan dengan Pendekatan Ilmu Sejarah, adalah satu kajian penting dan menarik. Namun demikian, pendekatanpendekatan hadith kontekstual dan Living Hadith dapat menambah pengembagan ilmu Hadith. Alasan-alasannya tidak berbeda dengan alasanalasan pentingnya kajian Living Qur'ān seperti diuraikan di atas.

Di Barat, kajian hadith memiliki motivasi yang beragam, ideologis, akademik, dan/atau keduanya. Yang lebih penting dan produktif adalah bahwa kajian-kajian mereka mengambil pendekatan-pendekatan yang beragam, seperti biografi, sejarah, tekstual, kontekstual, antropologis, sosiologis, filosofis, spiritualis, psikologis, dan lainnya. Pendekatan mereka bermula dari Orientalisme, lalu post-orientalisme, dan makin banyak kerjasama Muslim dan 
non-Muslim, melampaui perspektif outsider dan insider. ${ }^{35}$ Ada masih yang negatif polemikal, tapi makin banyak yang simpatik positif, rekonsiliatori sintesis, dan humanis. Ada pergeseran sikap Barat terhadap sosok Nabi Muhammad. Ada hubungan erat antara membaca Nabi Muhammad yang historis dan yang dipahami umat Islam sepanjang zaman. Pengaruh pendapat dan kajian Barat terhadap pemahaman dan kajian Muslim tentang Nabi Muhammad dapat dilihat dari kemajemukan pendekatan, kemajemukan pandangan, dan perdebatan populer dan akademik yang memperkuat kajian ilmiyah: kritis dan bertanggung jawab.

Kajian Naskah masih penting. Contoh saja, Martin Lings, tentang Muhammad: His Life Based on the Earliest Sources, ${ }^{36}$ memakai sumber-sumber primer sirah Nabi pada abad ke-8 dan ke-9 Masehi yang menceritakan kejadiankejadian kehidupan Nabi. Buku ini mengandung terjemahan bahasa Inggris dari banyak kalimat penting yang menjelaskan kata-kata laki-laki dan perempuan yang mendengar Nabi atau menyaksikan kejadian-kejadian hidupnya. Buku ini menggunakan pendekatan naratif yang mudah dipahami. Kajian lain melihat hadith sebagai scripture, membahas otoritas hadith dalam Islam. Dalam buku Hadith as Scripture: Discussions on the Authority of Prophetic Traditions in Islam, Aisha Y. Musa ${ }^{37}$ membahas perdebatan awal tentang otoritas hadith dan membandingkannya dengan perdebatan kontemporer.

Jonathan Brown adalah sarjana yang menggeluti soal hadith ini, melampaui pendekatan para Orientalis sebelumnya. Dalam bukunya Hadith: Muhammad's Legacy in the Medieval and Modern World, ${ }^{38}$ Brown menantang pendapat umum bahwa hukum Islam lebih bersumberkan pada al-Qur'ān. Menurutnya, hadith lebih populer ketimbang al-Qur'ān. Buku ini membahas pertanyaan-pertanyaan kompleks tentang otentisitas historis hadith-hadith, menguraikan koleksi dan kritik hadith dan mendiskusikan kontroversi seputar peran Hadith dalam kehidupan moderen Muslim.

Dalam bukunya yang lebih baru, Misquoting Muhammad: The Challenge and Choices of Interpreting the Prophet's Legacy, ${ }^{39}$ Brown berusaha

${ }^{35}$ Lihat Carl Ernst dan Richard Martin (eds), Rethinking Islamic Studies: From Orientalism to Cosmopolitanism (UNC Press, 2010).

${ }^{36}$ Martin Lings, Muhammad: His Life Based on the Earliest Sources (Islamic Texts Society, 1991).

${ }^{37}$ Aisha Y. Musa, Hadith as Scripture: Discussions on the Authority of Prophetic Traditions in Islam (Pelgrave Macmillan, 2015)

${ }^{38}$ Jonathan Brown, Hadith: Muhammad's Legacy in the Medieval and Modern World (London: Oneworld, 2009).

${ }^{39}$ Brown, Misquoting Muhammad: The Challenge and Choices of Interpreting the Prophet's Legacy (London: Oneworld, 2014). 
mendiskusikan bagaimana Nabi Muhammad dipahami dan disalahpahami baik oleh umat Islam maupun non-Muslim di Barat. Banyak aturan hukum Islam dan dogma berkembang kemudian, sepanjang abad oleh otoritas agama. Buku Misquoting Muhammad, menguraikan bagaimana kaum intelektual Muslim mencari keseimbangan antara akal dan wahyu dan menegosiasikan kebenarankebenaran kitab suci di tengah nilai-nilai yang berubah.

Sarjana Muslim lain di Amerika, Omid Safi dalam bukunya Memories of Muhammad: Why the Prophet Matters ${ }^{40}$ mencoba menjelaskan siapa Muhammad? Apa yang kita tahu tentang Muhammad secara historis dan apakah Muhammad dalam sejarah berbeda dengan Muhammad seperti dilihat dan diagungkan para pengikutnya? Buku Memories of Muhammad melihat Muhamad dari kacamata kelahiran Islam dan sejarah Islam yang panjang, mengambil tema-tema pokok seperti peperangan, status perempuan, posisi penting Jerusalem, dan ketegangan-ketegangan kontemporer antara Muslim, Yahudi, Hindu, dan Kristen. Safi juga membahas sedikit banyak seorang Muslim secara spiritual melakukan hubungan dengan Tuhan melalui Nabi mereka, di masjid, di rumah, dan di cyberspace.

Kajian mutakhir tentang biografi Muhammad adalah Kecia Ali, The Lives of Muhammad ${ }^{41}$ antara lain dilatarbelakangi kasus kartun dan video tentang Muhammad di Amerika dan di Eropa. Buku The Lives of Muhammad membahas banyak cara di mana Nabi diceritakan dari awal Islam sampai sekarang, oleh Muslim dan non-Muslim. Sejak abad ke-19, Ali berpendapat, ada corak penulisan: hagiografis yang memuja Nabi, dan polemik yang mengeritik Nabi, bergabung menjadi satu cerita yang terus diperdebatkan tentang Nabi. Semua orang, mulai dari misionaris Protestan, Orientalis Eropa, kaum pembaharu di India dan Mesir, dan Amerika, termasuk penceramah, Islamofob, wartawan, akademisi, guru-guru New Age, memperdebatkan karakter Muhammad dan fakta-fakta kehidupannya.

Tentang literatur hadith di Indonesia, Howard Federspiel telah melakukan survey dari zaman kolonial sampai tahun 1980an. Menurutnya, literatur hadith menempati posisi penting di Indonesia meskipun al-Qur'ān selalu menempati posisi utama. Pada era kontemporer, kaum pembaharu

40 Omid Safi, Memories of Muhammad: Why the Prophet Matters (HarperCollins, 2009).

${ }^{41}$ Kecia Ali, The Lives of Muhammad (Cambridge, MA: Harvard University Press, 2014). 
semakin menggunakan hadith untuk memperkuat identitas keislaman, melalui hukum Islam dan pemikiran sosial politik. ${ }^{42}$

Sejalan dengan Federspiel, antropolog Mark Woodward juga menulis artikel. Ia berpendapat, penggunaan teks hadith di Indonesia berfungsi pada kehidupan agama, sosial dan bahkan politik. Umat Islam di Indonesia, menurutnya, berusaha mewarnai masyarakat menurut cita-cita al-Qur'ān dan hadith sebagaimana yang mereka pahami. Mereka menggunakan terjemahanterjemahan hadith, seperti kumpulan hadith arba'in Imam Nawawi dan kitab Riyậ̣ al-Sälihin, untuk mengesahkan kerjasama antara NU dan pemerintah, dan sebagai kritik terhadap modernisme, dan kritik terhadap Islam kejawen yang menekankan Sufisme dan tidak memperhatikan fiqh. Woodward membahas bagaimana hadith-ḥadith tentang niat, ikhlas, jihad, dan hijrah, digunakan kaum Muslim di Indonesia yang memiliki makna dan dampak sosial dan politik. ${ }^{43}$

Kajian Living Hadith masih belum berkembang. Ada artikel-artikel menarik dan penting dikembangkan, misalnya Earle H. Waugh, "The Popular Muhammad: Models in the Interpretation of an Islamic Paradigm", yang membahas aspek experiential (pengalaman) terhadap sosok Nabi dalam sirah Ibnu Ishaq, dalam pemikiran modern, dan aktifisme kontemporer. ${ }^{44}$ Potensi kajian ini besar: Mengkaji bagaimana hadith (atau sosok Nabi Muhammad) dibaca, dihapal, dilagukan, dipahami, dan/atau diterapkan atau tidak diterapkan dalam kehidupan nyata individu, kelompok, atau masyarakat dalam ruang dan waktu tertentu. Kajian Living Hadith bisa membahas bagaimana tokoh, anggota masyarakat, atau kelompok Islam memahami dan/atau menerapkan hadithhadith tentang iman, tentang ibadah, akhlak, fiqh, jihad, warisan, perkawinan, dan sebagainya. Sumber-sumber kajian ini bisa berbentuk naskah tulisan, lisan, praktek kehidupan, dan kelembagaan. Menarik juga dikaji apakah (atau sejauh mana) hadith lebih populer dan lebih sering dijadikan referensi ketimbang ayatayat al-Qur'ān dalam kehidupan sehari-hari Muslim di ruang dan waktu tertentu. Atau, penting diteliti bagaimana ayat dan hadith saling menguatkan dalam kepentingan dan konteks tertentu.

${ }^{42}$ Howard Federspiel, "Hadith Literature in Twentieth Century Indonesia," Oriente Moderno 21 (82), 1 (2002): 115-124.

${ }^{43}$ Mark R. Woodward, "Textual Exegesis as Social Commentary: Religious, Social, and Political Meanings of Indonesian Translations of Arabic Hadith Texts," The Journal of Asian Studies 52, 3 (Agustus 1993): 565-83.

${ }^{44}$ Earle H. Waugh, "The Popular Muhammad: Models in the Interpretation of an Islamic Paradigm," Richad Martin (ed.), Approaches to Islam in Religious Studies (London: Oneworld, 2001), 41-58. 


\section{Perbedaan Kaidah dan Kaidah Penelitian, Perbedaan Teori dan Metode}

Dalam mengembangkan penelitian di bidang studi al-Qur'ān, tafsir, hadith, dan ilmu hadith, perlu dipikirkan tujuan pengajaran Studi Al-Quran dan Studi Hadith di UIN, IAIN dan STAIN. Jika kita ingin menciptakan mufassir atau muhaddith, maka mahasiswa harus belajar kaidah-kaidah dan metodemetode penafsiran dan ilmu hadith seperti selama ini sudah masuk kurikulum. Jika kita bertujuan menjadi para peneliti al-Qur'ān dan tafsir dan peneliti Hadith yang berkarakterisik ilmiah akademik maka banyak sekali yang harus diperbaharui dalam kurikulum dan metode pengajaran di UIN dan IAIN selama ini. Orientasi yang pertama, fokus pada kaidah tafsir, dalam arti ketetapanketetapan yang membantu mufassir menarik makna al-Qur'ān (seperti halnya Mantiq dan Ushul Fiqh). ${ }^{45}$ Jika kita ingin orientasi kedua, maka kita perlu fokus pada kaidah penelitian tafsir: Ketetapan-ketetapan yang membantu mahasiswa/sarjana mengkaji al-Qur'ān dan tafsir, tekstual maupun kontekstual, mengikuti perkembangan ilmu-ilmu sosial, humaniora, dan ilmu-ilmu lainnya.

Kajian-kajian yang mengacu pada orientasi kaidah tafsir juga menguat di Barat, khususnya untuk memberikan bimbingan bagi umat Islam yang berbahasa Inggris tentang metode memahami Al-Qur'ān secara "benar dan bertanggung jawab". Banyak buku-buku dalam bahasa Inggris mengenai metode memahami dan menafsirkan al-Quran dalam zaman modern, seperti Understanding the Qur'an, oleh Muhammad Abdel Haleem; Reading the Qur'an, oleh Ziauddin Sardar; the Qur'ān Guide oleh Farid Esack; dan Reading the Qur'an in the Twenty-First Century: A Contextualist Approach oleh Abdullah Saeed. Sardar misalnya, membagi tema-tema: seperti nabi-nabi dan wahyu, kebenaran dan pluralitas, akal dan pengetahuan, hak-hak dan kewajiban etika dan moral, alam dan lingkungan. Dia juga membahas topik-topik kontemporer seperti syariah, poligami dan kekerasan rumah tangga, seksualitas dan masyarakat, homoseksualitas, kebebasan berekpresi, bunuh diri, teori evolusi, seni dan musik. ${ }^{46}$ Para sarjana non-Muslim yang umumnya empatik dan obyektif memahami peran al-Quran bagi umat beriman, juga menghasilkan karya-karya semacam ini, seperti Michael Sells yang menulis Approaching the Qur'an: the Early Revelations; Carl W. Ernst, How to Read the Qur'an: A New

${ }^{45}$ M. Quraish Shihab, Kaidah Tafsir: Syarat, Ketentuan, dan Aturan yang Patut Anda Ketahui dalam Memahami Ayat-ayat al-Qur'ān (Ciputat: Lentera Hati, 2013), 11.

${ }^{46}$ Ziauddin Sardar, Reading the Qur'an: the Contemporary Relevance of the Sacred Text of Islam (London: Oxford University Press, 2011). 
Guide, with Select Translations ${ }^{47}$ dan Anna Gade, yang menulis pendahuluan terhadap the Qur'ān.

Di Timur Tengah, Kitabāt al-Baḥth al-'Ilmī Wa Mașādir al-Dirāsāt alIslämiyyah, memuat metodologi penelitian yang berfokus pada kajian naskah, dan membuat sumber-sumber kajian tafsir dan hadith yang semuanya berbentuk naskah. ${ }^{48}$ Metode penelitian Living Qur'ān dan Hadith pada dasarnya sama dengan penelitian sosial dan keagamaan yang lain: fenomenologis, antropologis, psikologis, sosiologis, dan sebagainya. Selain naskah, metode penelitian bisa pustaka, dokumen, juga ada wawancara, survey, kuesioner, dan pengamatan langsung.

Dalam hal ini, perlu juga dibedakan, teori adalah pernyataan-pernyataan bagaimana dan mengapa fakta-fakta tentang dunia sosial berhubungan, sedangkan metode adalah cara mengumpulkan fakta-fakta itu, seperti wawancara, dokumen, survey dan sebagainya. Teori-teori yang bisa digunakan secara menarik dan kritis terhadap Living Qur'ān dan Hadith adalah teori-teori kajian agama seperti antropologi agama, sosiologi agama, psikologi agama, dan ilmu sosial dan humaniora yang lain.

Secara umum, jika orientasinya kaidah penelitian, maka langkah-langkah penelitiannya serupa dengan penelitian pada ilmu sosial dan humaniora, mulai dari mencari masalah, membuat pertanyaan penelitian, mencari sumber dan mengumpulkan data, banyak membaca, menentukan pendekatan, menentukan teori dan konsep kunci, melakukan penelitian, membuat catatan-catatan, membuat outline, menulis draft, mendapatkan bimbingan kolega atau dosen, memperbaiki dan menulis draft akhir, dan menerbitkannya di jurnal atau sebagai buku.

Dengan langkah-langkah penelitian seperti itu, kita mungkin dapat menemukan jawaban-jawaban atas pertanyaan-pertanyaan seperti ini: Apa perbedaan peran al-Qur'ān (dan/atau hadith) bagi orang yang telah beriman dan bagi yang tidak beriman? Apa perbedaan peran al-Qur'ān (dah hadith) bagi orang Arab dan bagi orang bukan Arab? Sejauh mana ras dan suku berperan dalam pemahaman dan penerapan al-Qur'ān dan hadith? Bagaimana posisi kelas sosial ekonomi, pendidikan, jender, atau nasionalisme? Apakah pengaruh alQur'ān dan hadith berbeda bagi orang-orang Mesir dan bagi orang-orang Indonesia? Apakah ada perbedaan pemahaman al-Qur'ān orang Syiah di Iran

${ }^{47}$ Carl W. Ernst, How to Read the Qur'an: A New Guide, with Select Translations (the University of North Carolina Press, 2011).

${ }^{48}$ Abdul Wahhab Ibrahim Abu Sulaiman, Kitābāt al-Bahth al-'Ilmī Wa Maṣādir al-Dirāsāt al-Islāmiyyah (Jeddah, Saudi: Dār al-Shurūq, 1986). 
dan Sunni di Indonesia? Adakah perbedaan sikap orang tua, anak muda dan remaja terhadap al-Qur'ān dan hadith? Bagaimana mereka yang di perkotaan dan di pedesaan? Living Qur'ān dan Hadith menelusuri konteks ruang dan waktu di sini dan kini.

\section{Penutup}

Tulisan ini merupakan survey kajian-kajian kontemporer tentang alQuran dan hadith (termasuk tentang sosok Nabi Muhammad), khususnya di Barat (dengan beberapa contoh kajian di Timur Tengah dan Indonesia). ${ }^{49}$ Kajian Naskah al-Qur'ān dan hadith tetap penting dan harus dikembangkan. Namun, kajian Living Qur'ān dan Living Hadith memiliki peluang yang besar. Kelemahan-kelemahan pada kajian naskah tekstual dapat ditutupi dengan kelebihan-kelebihan kajian kontekstual praktikal. Sebaliknya, kekurangankekurangan pada kajian kontekstual dapat ditutupi denga kajian tekstual. Para pengkaji studi al-Qur'ān dan hadith memiliki peluang yang besar dan beragam dari segi topik, pendekatan, metode, dan sumber-sumbernya. Setiap kitab, scripture, muncul dari realitas tertentu dan berfungsi di realitas pula. Realitas sebelum, ketika, dan setelah kitab suci menjadi kitab suci, sangat penting diteliti, tapi tidak kalah pentingnya dikaji realitas masa kini di mana kitab itu dianggap hidup (living). Aspek-aspek kognitif dan non-kognitif, dan aspekaspek informatif dan performatif dari penggunaan kitab suci yang hidup itu dapat menjadi fokus penelitian al-Quran dan/atau hadith. Tentu saja kajiankajian ini tergantung pada motivasi, disiplin, kreatifitas, kemampuan berbahasa, keterampilan metodologis, kemudahan akses pada sumber primer dan sekunder, dukungan birokratis dan finansial dari lembaga pendidikan terhadap pengembangan budaya riset dan menulis.

\section{Daftar Pustaka}

Abu Sulaiman, Abdul Wahhab Ibrahim. Kitābàt al-Baḥth al-'Ilmī Wa Masāàr al-Dirāsāt al-Islāmiyyah. Jeddah, Saudi: Dār al-Shurūq, 1986.

Ali, Kecia. The Lives of Muhammad. Cambridge, MA: Harvard University Press, 2014.

${ }^{49}$ Lihat juga Sahiron Syamsuddin (ed.), Metodologi Penelitian Living Qur'an dan Hadis (Yogyakarta: TH-Press, 2007). 
Ali, Muhamad. "'They Are Not All Alike': Indonesian Muslim Intellectuals' Perception of Judaism and Jews." Indonesia and the Malay World 38, 112 (November 2010): 329-47.

-------. "Review of Perfection Makes Practice." the American Journal of Islamic Social Sciences 23, 3 (2006): 89-91.

Baidan, Nashruddin. Tafsir Maudhu'i: Solusi Qur'ani atas Masalah Sosial Kontemporer. Yogyakarta: Pustaka Pelajar, 2001.

Bintu Al-Shāti', ‘'̄'ishah Abd al-Rahman. Al-Qur’ān wa Qạ̣āāa al-Insan. Kairo: Dar al-Ma'arif, tanpa tahun.

Brown, Jonathan. Hadith: Muhammad's Legacy in the Medieval and Modern World. London: Oneworld, 2009.

-------. Misquoting Muhammad: The Challenge and Choices of Interpreting the Prophet's Legacy. London: Oneworld, 2014.

Ernst, Carl W. How to Read the Qur'an: A New Guide, with Select Translations. The University of North Carolina Press, 2011.

-------- dan Richard Martin eds. Rethinking Islamic Studies: From Orientalism to Cosmopolitanism. UNC Press, 2010.

Farrin, Raymond. Structure and Qur'ānic Interpretation: A Study of Symmetry and Coherence in Islam's Holy Text. While Cloud Press, 2014.

Federspiel, Howard M. "Hadith Literature in Twentieth Century Indonesia." Oriente Moderno 21 82, 1 (2002): 115-124.

-------. Popular Indonesian Literature of the Qur'an. Ithaca: Cornell Univrsity Modern Indonesia Project, 1994.

Gade, Anna. Perfection Makes Practice: Learning, Emotion, and the Recited Qur'ān in Indonesia. Honolulu: University of Hawai'i Press, 2004.

. "Taste, Talent, and the Problem of Internalization: A Qur'ānic Study in Religious Musicality from Southeast Asia." History of Religions 41, 4 (May 2002): 328-68.

Ghazali, Dede Ahmad dan Heri Gunawa., Studi Islam: Suatu Pengantar Dengan Pendekatan Interdisipliner. Bandung: Remaja Rosdakarya, 2015.

Al-Ghazāì, Muhammad. Naḥwa al-Tafsir al-Mau'ḍu' $\bar{i}$ li Suwar al-Qur'ān alKarīm: Al-Ajz̄a' al-'Asharāt al-Ūlā. Kairo dan Beirut: Dār al-Shurūq, 1992.

Gibson, Thomas. "Review of Perfection Makes Practice." Indonesia 79 (April 2005): 183-185.

Graham, William. "The Qur'ān as Spoken Word: An Islamic Contribution to the Understanding of Scripture." Richard Martin, ed. Approaches to Islam in Religious Studies. London: Oneworld, 2001, 23-40. 
Hidayatullah, Aysha A. Feminist Edges of the Qur'ān. Oxford University Press, 2014.

Kersten, Carool. "Review of Abdullah Saeed ed., Approaches to the Qur'an in Contemporary Indonesia." Bulletin of the School of Oriental and African Studies 69, 3 (2006): 499-501.

Lessa, W.A. dan E.Z. Vogt, Reader in Comparative Religion: An Anthropological Approach. New York: Harper dan Row, 1997.

Lings, Martin. Muhammad: His Life Based on the Earliest Sources. Islamic Texts Society, 1991.

Mattson, Ingrid. The Story of the Qur'an: Its History and Place in Muslim Life. Wiley-Blackwell, 2008.

Maynard, Jane F. et al, eds. Pastoral Bearings: Lived Religion and Pastoral Theology. New York: Lexington Books, 2010.

Musa, Aisha Y. Hadith as Scripture: Discussions on the Authority of Prophetic Traditions in Islam. Pelgrave Macmillan, 2015.

Nata, Abuddin ed. Ilmu-ilmu Al-Qur'an. Bagian 1. Jakarta: Biro Bina Mental Spiritual DKI Jakarta, 1993/1993.

Nelson, Kristina. "Review Anne K. Rasmussen, Women, the Recited Qur'ān, and Islamic Music in Indonesia." Review of Middle East Studies 46, 1 (Summer 2012): 134-6.

Rasmussen, Anne K. "The Qur'ān in Indonesian Daily Life: the Public Project of Musical Oratory." Ethnomusicology 45, 1 (Winter 2001): 30-57.

-------. Women, the Recited Qur'ān, and Islamic Music in Indonesia. Berkely: University of California Press, 2010.

Saeed, Abdullah. Ed. Approaches to the Qur'ān in Contemporary Indonesia. London: Oxford University Press in association with the Institute of Ismaili Studies, 2005.

Safi, Omid. Memories of Muhammad: Why the Prophet Matters. HarperCollins, 2009.

Sardar, Ziauddin. Reading the Qur'an: the Contemporary Relevance of the Sacred Text of Islam. London: Oxford University Press, 2011.

Shihab, M. Quraish. Kaidah Tafsir: Syarat, Ketentuan, dan Aturan yang Patut Anda Ketahui dalam Memahami Ayat-ayat al-Qur'ān. Ciputat: Lentera Hati, 2013.

-------. Membumikan Al-Qur'ān. Jilid 1 dan jilid 2. Bandung: Mizan, 2008.

Sirry, Mun'im A. Scriptural Polemics: the Qur'ān and Other Religions. London dan New York: Oxford University Press, 2015. 
Smith-Hefner, Nancy J. "Review Pieternella van Doorn-Harder, Women Shaping Islam: Reading the Qur'ān in Indonesia." The Journal of Asian Studies 67, 2 (May 2008): 747-49.

Syamsuddin, Sahiron ed. Metodologi Penelitian Living Qur'an dan Hadis. Yogyakarta: TH-Press, 2007.

Umar, Nasaruddin. Deradikalisasi Pemahaman Al-Qur'an \& Hadis. Jakarta: Gramedia, 2014.

van Bruinessen, Martin. "Review of Popular Indonesian Literature of the Qur'ān." Journal of Southeast Asian Studies 29, 1 (Maret 1998): 197-99.

van Doorn-Harder, Pieternella. Women Shaping Islam: Reading the Qur'an in Indonesia. Urbana: University of Illinois Press, 2006.

van Voorst, Robert E. Anthology of World Scriptures. Belmont, CA: Thomson Wasworth, 2008.

Wadud, Amina. Qur'ān and Women: Rereading the Sacred Text from a Woman's Perspective. London: Oxford University Press, 1999.

Ware III, Rudolph T. The Walking Qur'ān: Islamic Education, Embodied Knowledge, and History in West Africa. The University of North Carolina Press, 2014.

Waugh, Earle H. "The Popular Muhammad: Models in the Interpretation of an Islamic Paradigm.” Richad Martin ed. Approaches to Islam in Religious Studies. London: Oneworld, 2001, 41-58.

Woodward, Mark R. "Textual Exegesis as Social Commentary: Religious, Social, and Political Meanings of Indonesian Translations of Arabic Hadith Texts." The Journal of Asian Studies 52, 3 (Agustus 1993): 56583.

Adz-Zhahabi, Muhammad Husein. Penyimpangan-penyimpangan dalam Penafsiran Al-Qur'an. Terj. Hamim Ilyas dan Machnun Husein. AlIttijāhāt al-Munharifah fi Tafsìr al-Qur'ān al-Karim. Jakarta: Rajawali, 1991. 